\title{
水制群を含む木曾川下流域の出水時の 流れ構造とワンド地形の変遷 \\ FLOW STRUCTURE ON GROINS DURING FLOOD EVENT AND MORPHOLOGICAL EVOLUTION OF TOPOGRAPHY
}

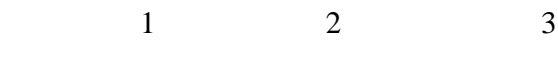 \\ Ryota TSUBAKI, Hisashi FURUHATA, and Tetsuro TSUJIMOTO

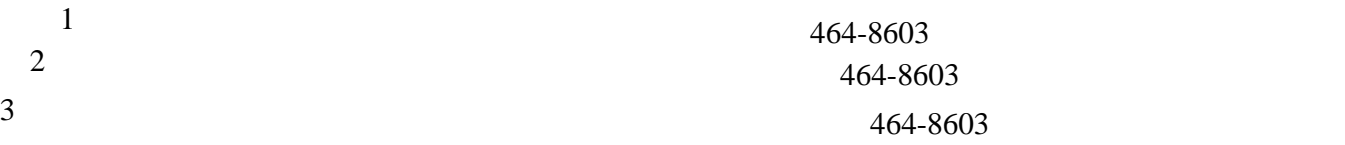

\begin{abstract}
Morphological evolution of the topography of the reach with groins is investigated using a numerical model solving the two-dimensional shallow water equations in this study. A flood event is represented to discuss the dischargedependent change of the interaction between flow structure and sediment transport. The primary flow is meandering according to alternate or multiple bars formed in the channel during low-water and medium-water periods, and it is found that deposition of the fine sand and silt on vegetated area between groins is affected by the meander of primary flow. During a high-water period, on the contrary, the primary flow follows the large-scale topography of the river so that flow on the flood plain is also straightforward according to the large-scale channel form. This straightforward flow on the flood plain, formed between groins, induces three-dimensional flow structure (longitudinal vortex), develops streak go through the groins longitudinally, and forms the rib-shaped topography on the flood plain. This ribbed bathymetry is highly interacting with sediment transport not only within the flood plain but also between the channel and the flood plain.
\end{abstract}

Key Words: Kiso river, groin, sediment transport, ecological functions, ecosystem services

1. はじめに

河川の水辺の環境は弚の周辺の生態に大きな影響を 及ぼす. 水辺は主流部に比べて流速が遅いため昆虫類 の幼生や魚類の稚魚などの小型水棲動物の生息域とし て不可欠であり ${ }^{1)}$, 鳥類等の採餌場としても重要な役 割を果たす．植物についても，浅水域には沈水や湿性 等の群落を形成し，平水時には干出する領域において は草本類や木本類が生育するなど水際の周辺には多樣 な植物がみられる ${ }^{2)}$. 水辺は河川の両岸に沿った帯状の 領域であり，河道や炎の周辺の地形の流域等のスケー ルと比べると，わずかな面積を占めるのみであるが上 記のように生態系にとって重要な役割を担っている．

河川の周囲の生態系にとって, 出水は生存を脅かす 事象であるとともに栄養の供給や侵入・定着のきつか けとなるなど多面的な役割を担っている．自然状態の 河川中下流域にみられる自然堤防帯やデルタ地帯では， 出水時には, 水域が平水時から大きく拡大されて, 氾 濫域へと浅水域・水際が一時的に拡張され，続いて出 水の減衰とともに水域の一部を汇濫域へ残しつつ，平 水時の河道へと水域が後退・集約されていく.このよう な自然状態の出水のプロセスによる広大な面積への一 時的な汇濫は, 人々の居住, 耕作, 商工活動にとって
は不都合な面も多く, 人々の生存を直接脅かすことも 少なくない，弚のため氾濫の制御は河川管理の重要な 目標であり，これは今日でも変わりはない．河川管理 技術によって治水・利水という近代社会に不可欠な機 能が実現されているが，さらに近年ではこれらの役割 に加えて環境機能の確保・向上が重要視されつつあり， 生態系サービスの享受や多樣性の確保, より大きくは 持続可能な社会の実現などのために河川・特に水辺の 環境の保全・向上が不可欠であるとの認識が広まりつ つある .

水制による流れの制御は，主に治水機能の発揮を狙 う河川管理技術であり，汇濫の常襲地帯であった木曽 三川の中下流部の河道安定化にも重要な役割を果たし た . 光の後, ダムによる出水の制御や土砂動態の変化 などの影響を受け, 河床形態も緩やかに変化しつつあ り，木曽川に設置された水制群周辺には，土砂の堆積 が進みワンドが形成され浅水域の現出や水際の多樣化 がみられ，樣々な生物の生息場となっている．このよう に，水制のもたらす効果として，弚の周辺に形成され るワンドなどの景観や樣々な水域の出現による水理環 境の多樣化 ${ }^{3)}$ や さらには兴の周辺に及 3 泩態系の多 樣性の確保等の環境機能が認められつつある.つまり 水辺が広大な氾濫原と共に本来担っていた生態系サー 


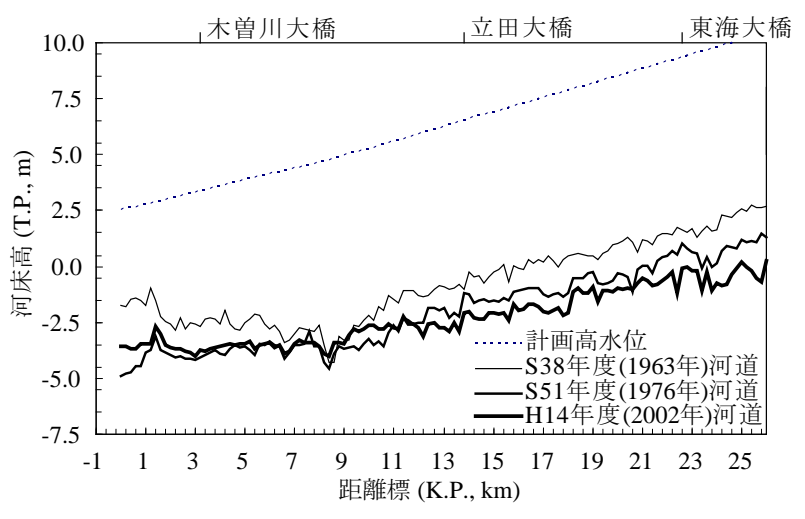

図-1 縦断河床形状の変遷

ビスの提供や多樣性を，堤外地という限られた領域・面 積にいわば押し込められた河道や水辺が発揮するため の有効かつ貴重な手段と考えられており，治水と環境 の両立という観点からも，ワンドの持つ生態的機能は 大いに期待されている．しかしながら，ワンドの形成・ 管理技術はいまだ確立されておらず，堆積による浅水 域の消滅などを防ぎつつワンドのもつ生態的機能を長 期的に持続・向上させるための方策は明らかではない 弚こで, 本研究では木曽川下流部（主に河口から 17 $24 \mathrm{~km}$ 周辺) のワンドが形成されている連続水制区間 の流れ構造を調査してワンドの形成・維持機構につい て考察することとした .

\section{2. 研究対象の概要}

图-1に研究対象区域の低水路平均河床高の縦断変化 の変遷を示す. 当区域においては全体的に河床低下の 傾向がみられ, 弚の原因として地下水くみ上げに起因 する広域的な地盤沈下, 各么建設等による供給土砂量 の減少, 砂利採取目的の河道掘削の三要因か指摘され ている ${ }^{3)}$. 流域における最初の公建設は 1924 年に建
設が開始された発電目的の大井ダムであり，研究対象 区域の直上流の $26 \mathrm{~km}$ 地点には 1970 年に馬飼頭首工の 建設が開始された .

図-1において，砂利採取が $1972-1990$ 年まで行われ た $13-24 \mathrm{~km}$ 区間において低水路の河床低下が見られ ることや，低水路と水制域内の河床高の変化の比較 ${ }^{4)}$ では水制域内の高さはあまり変化せず, 低水路側の高 さが低下することによって相対的に水制域内が高水敷 化していることから水制域内の高水敷化は, 砂利採取 の影響や供給土砂量の減少が主に寄与しているものと 思われる .

図-2 には $1948-2007$ 年の $21-23 \mathrm{~km}$ 区間の河道区 間の景観の変遷を河床形状 (2007 年) および航空写真 (2007 年以外) により示したものである . 図-2a) から水 制域内への堆砂は 1948 年時点までは発生しておらず， 图で示した範囲の上下流においても 1963 年以前には水 制区間内への堆砂は認められないこと ${ }^{4)}$ から，上記の 三要因のようなきっかけによって水制域内への堆砂が 促進され，干出域の一旦出現した後には，さらに植生侵 入による高水敷化の進行 ${ }^{5)}$ が起きると考えられる. 水 制区域内人堆砂がみられない場合でも，水制による流 速低減効果などの水棲動物への生態的機能は発揮され るものの, 水際の物理環境や生態系の多樣化という観 点では陸域と水域が共存するワンドの形成は水棲動物 に限らず，周辺の植生や陸生動物にまで波及する多樣 な生態的機能を提供するものと考えられる一方で, 侵 入した植生により土砂捕捉が促進されるため, 高水敷 化の傾向がみられることが，ワンドの形成・管理を考 える上で重要課題となる .

図-2に示した五つの時点での低水路の河床形態に注 目すると，1948 年ごろは多列砂州に近い形態であるが 時間の経過とともに複列, 交互砂州へと大規模化してい る樣子が伺える．ただし，1975 年および 1982 年は, 砂 利採取が行われていた期間であり，図-2b)および図-2c) 内の丸で示した部分に採取跡か認められる．木曽川で は 1983 年に大きな出水が発生し, 弚の後の 1987 年お

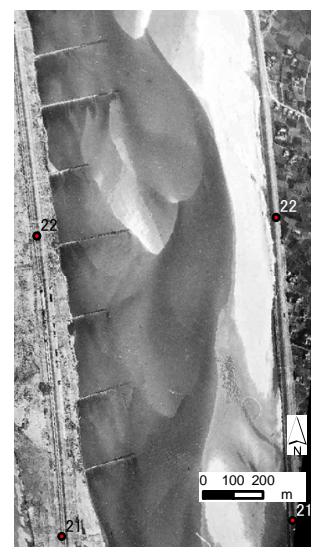

a) 1948 年

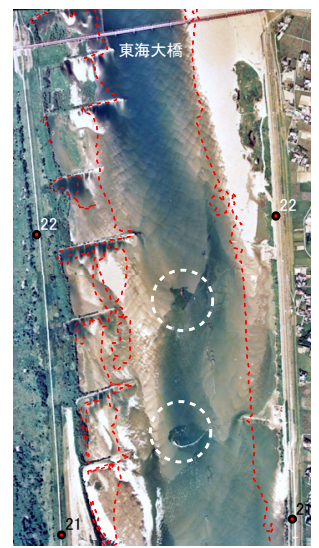

b) 1975 年

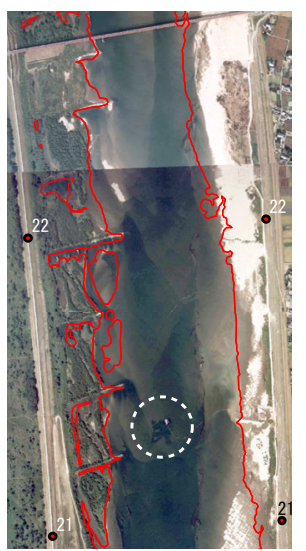

c) 1982年

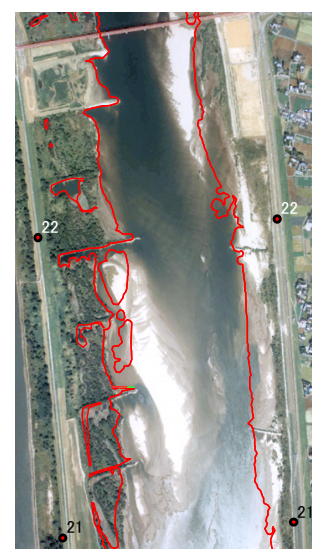

d) 1987年

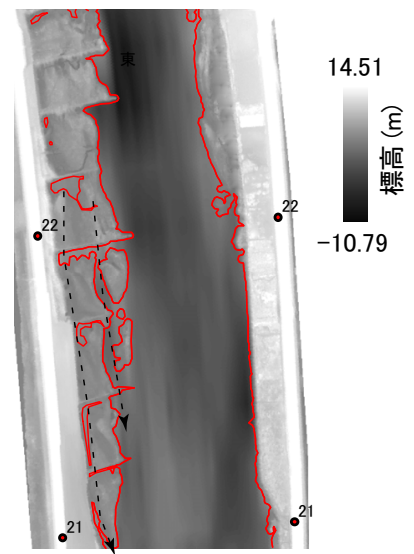

f) 2007年（標高）

図-2 水制区間の景観の変遷 


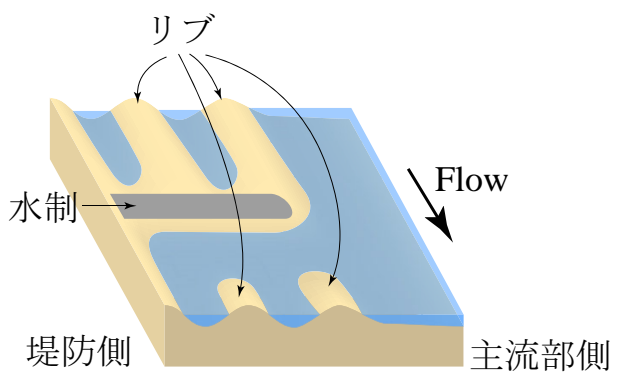

図-3 リブ状地形の概念図

よび 2007 年の河床形態はほとんど変化しておらず澪筋 か緩やかに蛇行した状態で安定している. 図-2f)の水制 区間内の水際の位置および標高分布に注目すると，図 中に黑点線矢印で示した位置には, 局所的な深掘部が 水制を越えて縦断的に連続する水路状の形態が平行し て連なるリブ状の地形 (図-3 を参照) が形成されてお り，このような地形の形成機構については次章の最後 に改めて議論する .

既往研究の中で, 流れ構造とワンド地形の変遷につ いては樣々な観点での検討が行われており，航空写真 を用いたワンド地形の類型化や変遷の検討 ${ }^{4)}$, 水制背 後の洗掘と前面での堆積に注目した鉛直二次元モデル による検討 ${ }^{3)}$ ，準平面二次元モデルによる低水路およ び水制域内の河床変動条件の検討 ${ }^{3,6)}$, 水制角度と河床 変動の関連の検討 ${ }^{7,8)}$ などが実施されている．しかし， 主流部の砂州形態や流れの蛇行と水制域内の堆砂の関 連や，ワンド内に形成される流下方向の水路状地形の 形成機構は検討されていない.よって本研究では, 平 面二次元数值モデルによる出水時の流れの評価と航空 レーザー測量により得られた詳細なワンド地形の分析 により，ワンドの形成・維持機構について考察するこ ととした .

\section{3. 水制区間の出水時の流れ構造の検討}

前章で検討した河道地形の分析および変遷を踏まえ て, 本章ではワンドの形成・維持機構について考察す る. 具体的には, 平面二次元数值モデルにより出水時の 流れの評価を行い流れ構造とワンド地形の関連を議論 する. 数值モデルには非構造三角格子を計算格子に用 い, 有限体積法および FDS 法を用いて浅水流方程式を 離散化した ${ }^{9)}$.計算格子は，図-4に示すように水制・ワ ンド区間の地形を解像するために格子幅 (三角の辺の 長さ) か約 $10 \mathrm{~m}$ の比較的密な格子を配置し, 弚れ以外 の区間では最大約 $100 \mathrm{~m}$ の格子幅の格子を用いた . 計 算区間は $0 \mathrm{~km}$ から $25 \mathrm{~km}$ 地点までとした . 底面粗度 は $n=0.02$ とした ${ }^{6)}$. 河床形状については, 平水時の 干出域は 2007 年に実施された航空レーザー測量データ に基づく地盤高さ情報を用い，冠水域については 2003 年の横断測量データを補間したものを与えた (河床形

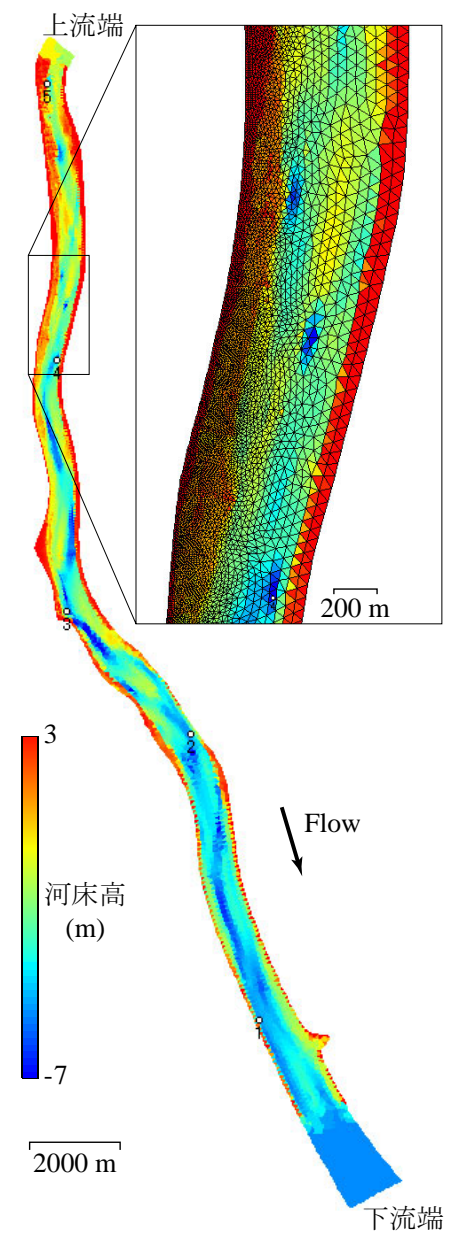

図-4 計算格子と河床高コンター

状の一部を図-2f)に示した）。

$17 \mathrm{~km}$ 地点付近より上流の水制域内などには植生が 存在するため, これらの流れへの抵抗を評価するため に抵抗項を基礎式に組み込んだ ${ }^{10,11)}$. 植生の密生度は $0.025 \mathrm{~m}^{-1}$ の一定值とし ${ }^{10)}$, 植生高さについては航空 レーザー測量により算出された高さを与えた (図-6a)) . 水制周辺には現状では土砂の堆積がみられ，特に上 流側で著しいことから，水制単体での流れの影響は大 きくなく弚の周辺の堆積状況を含んだ効果が支配的で あると考え，水制単体の付加抵抗等は考慮していない，

図-5に示すのは計算領域の上流端で与えた流入流量 の時間変化である .ピーク流量は 1976 年から 2005 年 の各年の年最大流量の平均値である $6820 \mathrm{~m}^{3} / \mathrm{s}$ とし , 流 量波形は 1983 年の出水の形状を用いた .

前章で示したように 1983 年以降は河床形状の大幅な 変化はみられないことから固定床として計算を行い, 流 れ構造と底面摩擦速度に着目してワンドの形成・維持 機構を検討する. 图-6b) は, 図-5 中に点 A で示した出 水初期の流速分布である. 低水路に形成された砂州形 態に合わせて澪筋部が蛇行している樣子が確認できる． 図-6c) には，同時刻の河床に働く摩擦速度 $u_{*}$ が研究対 象区域の河床材料の平均粒径に対する Shields の移動限 


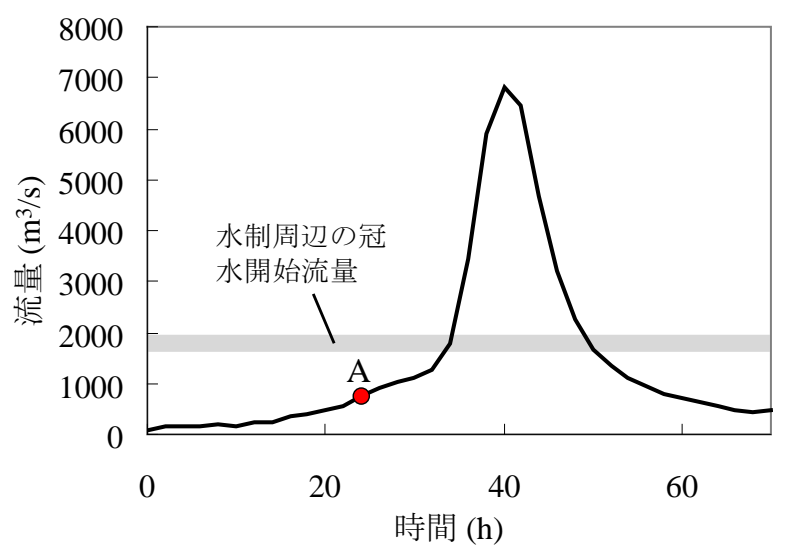

图-5 流入流量の時間変化(ハイドログラフ)

界摩擦速度 $u_{* c}$ を超える部分を示しており，この時点 (流量 $740 \mathrm{~m}^{3} / \mathrm{s}$ ) から澪筋部で河床材料の掃流が始まっ ていることがわかる . 次に , 図-6d)に示すのは出水ピー ク時の流速分布である . 流速の速い主流部は，河道の 中央部分に河道に沿って形成されており，図-6b)に示 したような出水初期もみられる低水路の砂州に沿った
蛇行とは流れの形態が大きく異なっている . 図-6e) に 示すのは, 出水ピ一ク時の摩擦速度 $u_{*}$ と移動限界摩擦 速度 $u_{* c}$ および Rubey による浮遊砂の沈降速度 $w_{0}$ の関 係を示したものであり，出水ピーク時には水制区域内 では掃流砂が, 低水路部では浮遊砂が河床変動に支配 的であることが確認できる．ただし，低水路部におい ても $u_{*}$ は $w_{0}$ より大きいもののオーダーは同程度であ ることから，平均年最大流量程度では現状では低水路 の河床の変動量は光れほど大きくないことが改めて確 認できる .

高水敷化した水制域内の表層土壤はシルト分を多く 含む微細土砂で覆われており，砂質である低水路の河 床とは相違が見られる ${ }^{5,12)}$.よって，浮遊した細粒分が 主流部にくらべて流速の遅い高水敷の植生区間で沈降 していると考えられ，高水敷への冠水が始まる流量約 $2000 \mathrm{~m}^{3} / \mathrm{s}$ 程度の出水初期および咸衰期にワンドで浮遊 砂の堆積が進行すると考えられる.一方, 出水ピーク時 には高水敷においても $u_{*}>u_{* c}$ となっており掃流砂と して洗掘を含む河床変動が発生すると考えられる . こ れらの出水初期・減衰期および出水ピーク時の流れ構造 と，ワンド地形の関連を図-7 を用いて検討する . 図-7a) に示したのは, 出水初期・減衰期に相当する流量での主

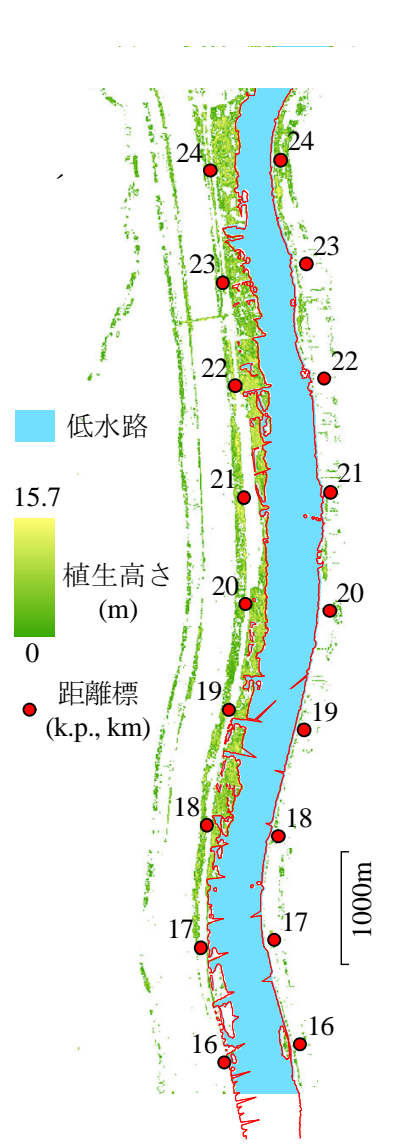

a) 植生高さの分布

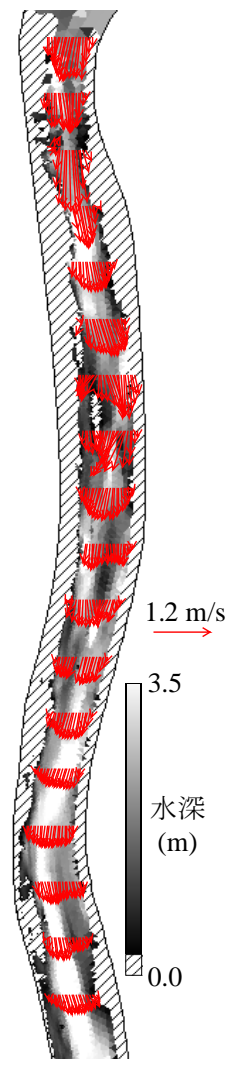

b) 出水初期の流速 ベクトルと水深 分布

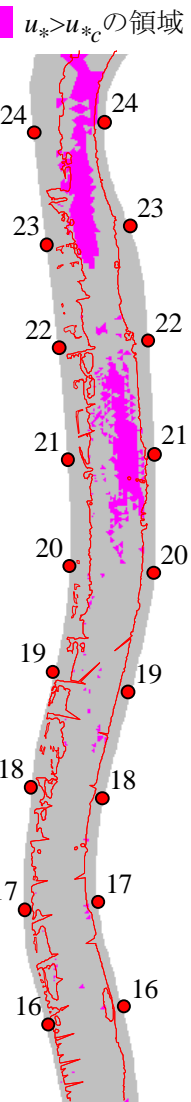

c) 出水初期の 掃流砂領域

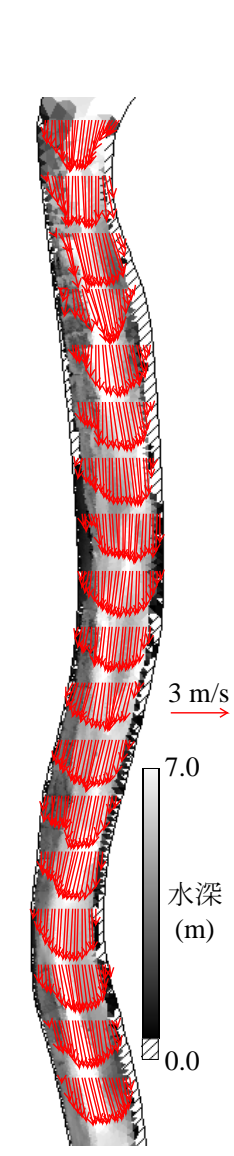

d) 出水ピーク時の 流速ベクトルと 水深分布

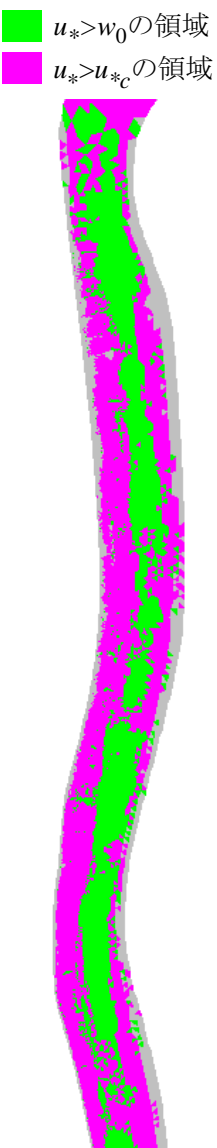

e) 出水ピーク時の掃 流砂・浮遊砂領域

図-6 流速分布の変化と河床材料の移動限界 


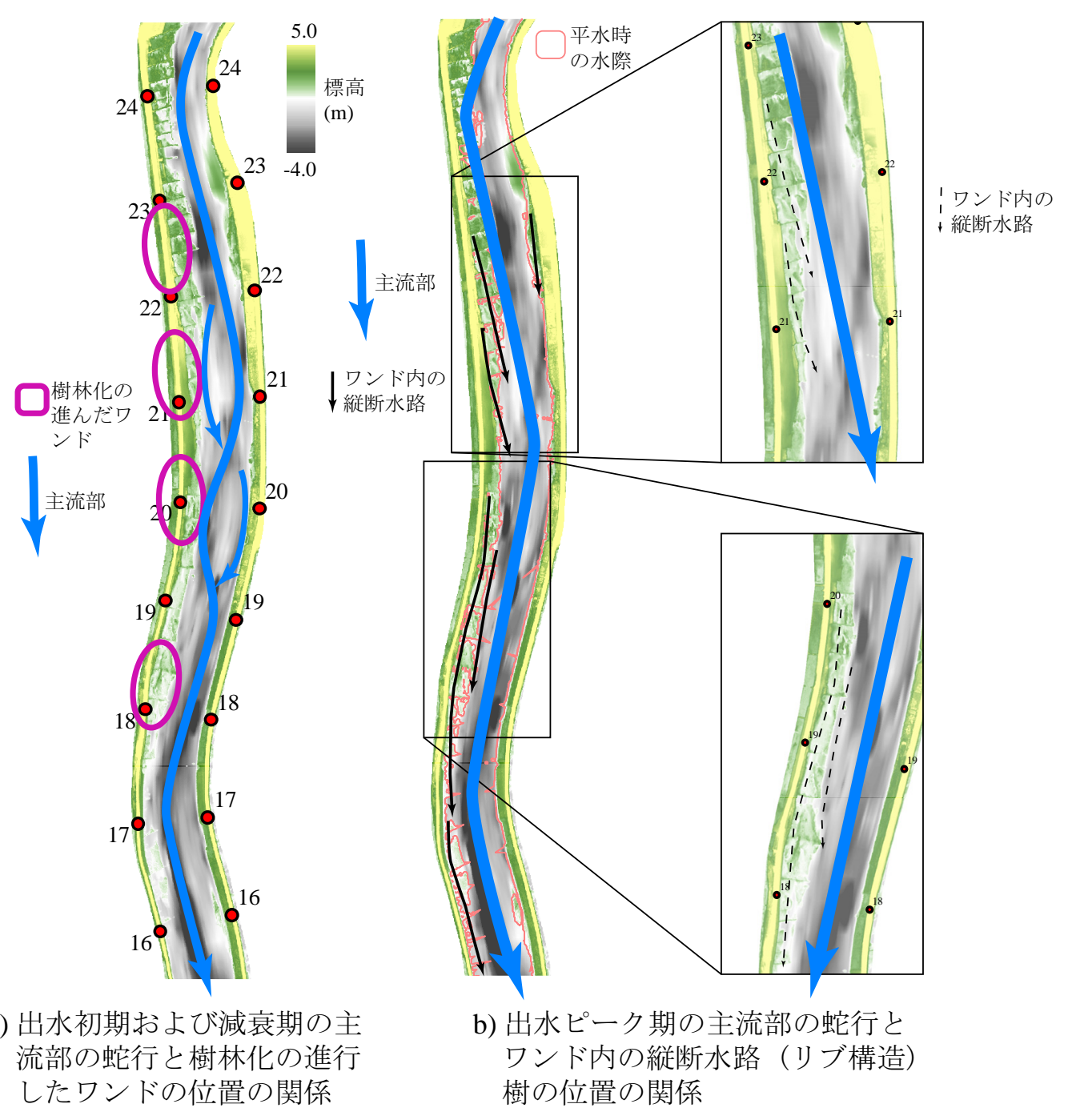

図-7 水制区間の出水時の流れ構造の概念図

流の位置と，堆砂が進行して樹林化の進んだワンドの 位置 ${ }^{13)}$ の関連を示したものである . 同図から澪筋の蛇 行周期と樹林化の著しいワンドの間隔がほぼ等しく位 置にも関連か認められる . 水制区間の表層付近の地層 はボーリンク調査から ${ }^{6)}$, 砂質 (粒径 $0.5 \mathrm{~mm}$ 程度) と シルト質がはっきりと分かれた層状の構造となってお り，表層付近に関しては植生域および水制近傍にシル 卜質が確認されており，光れ以外の部分は砂質の材料 で覆われている．水制区間は，図-6e) に示したの移動 限界領域の区分から，出水ピーク時には砂質の材料が 掃流されている状態であり，より粒径の小さな細粒分 の巻き上げも盛んであると推察される. 以上の樹林化 域と出水初期・減衰期の澪筋の蛇行との関連性および, 砂質の移動限界から, 樹林化域においては, 出水初期 や減衰期にウォツシュロードに近い形態て輸送された細 粒分が供給され，堆積が進行するものと考えられる．

主流の位置と樹林化の進んだワンドの位置関係につ いて, $24 \mathrm{~km}$ 付近および $18 \mathrm{~km}$ 付近では主流位置か離 れているものの樹林化の進行がみられない . $24 \mathrm{~km}$ 付近 については直上流で河道の屈曲や川幅の狭窄がみられ，
また $19 \mathrm{~km}$ 付近には旧堤防の遺構が河道を斜めに横断 するように存在しているため, 流れの特徵が異なって いるものと推察される.また，18 km より下流側では， 海水面による背水によって水制天端に対して相対的に 水位が高く保たれることから水制の流れに対する影響 が上流に比べて小さく，高水敷化が進みにくいためと 考えられている4).

次に，図-7b)には出水ピーク期の主流の位置と，ワ ンド内に見られる縦断方向に連続したリブ状の地形の 関連を示したものである . 同図から出水ピーク期の主 流方向と平行なリブ構造が形成されていることが確認 できる.よって，このリブ構造は出水ピーク時におい てみられる大規模な流れの構造と強く関連しているも のと考えられる .

\section{4. おわりに}

本研究では, 連続水制区間に形成されたワンドの形 成・維持機構を, 河道地形の分析および平面二次元数 
値モデルによる出水時の流れの評価を併用して検討し た . 河道に対する水制角度の影響の他は，従来ほとん ど検討されてこなかった主流部の流れ構造とワンド地 形の関連を出水プロセスとともに検討した . 弚の結果 高水敷の冠水が始まる出水初期および減衰期では主流 部の砂州に沿った蛇行がみられ，水制域内への細粒土 砂の供給が主流部の蛇行の影響を受けるため，樹林化・ 高水敷化の進みやすい位置が蛇行に合わせて存在する ことが明らかになった . 次に, 出水ピーク時には主流 部の蛇行がより大規模化し，この流れに平行したリブ 状の地形がワンドでみられることから，ワンド内にみ られる縦断方向に連続した水路状の構造は出水ピーク 時に形成・維持されることが示唆された .

リブ状の地形の形成機構としては, 主流部を流れる 比較的高濃度の土砂が横断混合によって水制や植生に より流速が抑えられている水制区間へと供給されて堆 積するという，いわば平面二次元的な機構 ${ }^{14)}$ と, リブ の底部分では高速流が発生し土砂を流下させるととも に，降下した流れが左右の丘部へと循環する二次流の 発生により土砂が丘部へと供給される縦滑構造 ${ }^{15,16)}$ が 形成されるという縦断鉛直二次元的な現象の二つが考 えられる.いずれにしろ，図-7b)に示したようにリブ 構造の下流は低水路へと接続していることから，水制 域内から主流部への土砂排出効果も担っているものと 考えられるため, 高水敷化の進展しがちなワンド地形 の維持，このようなリブ構造に沿って形成される高速 流は，ワンド周辺の水理環境や生態系の多樣性を長期 的に維持していくために注目すべき流れ構造と考えら れる.ただし，具体的な流れ構造や土砂動態を把握す るために, 土砂の濃度分布の解析や流れの三次元解析 などを行う必要があり今後の課題である.

謝辞 : 本研究を進めるにあたり国土交通省中部地方整 備局の木曽川下流河川事務所ならびに中部技術事務所 に貴重かつ重要な情報を提供いただきました．ここに 深甚な感謝を申し上げます. 名古屋大学田代喬助教に は多くの助言及び協力をいただました . 名古屋大学修 士課程塩之谷仁大君にはデータ整理に協力いただきま した . 本研究は文部科学省科学技術振興調整費「伊勢 湾流域圈の自然共生型環境管理技術開発（代表 : 辻本 哲郎)」の一環として実施したものです．

\section{参考文献}

1) R. C. Wissmar and R. L. Beschta. Restration and management of riparian ecosystems: a catchment perspective. Freshwater Biology, Vol. 40, pp. 571-585, 1998.

2) G. P. Malanson. Riparian landscapes. Cambridge university press, 1993.

3) 河川懇談会共同研究. 平成 11 年 13 年度, 河川懇談会, 2003.

4) 北村忠紀, 山田敦夫, 过本哲郎. 水制背後の局所的河床低 下によるわんど地形の形成. 河川技術論文集, Vol. 7, pp. 327-332, 2001.

5) 篠田孝, 水谷直樹, 松山康忠, 辻本哲郎. ケレップ水制周辺 の地形履歴から見たワンド形成過程と水辺環境の特性に 関する考察. 河川技術論文集, Vol. 7, pp. 333-338, 2001.

6) (財) 国土技術センター. 第二回委員会資料, 財団法人国 土開発技術研究センター, 2001.

7) 冨永晃宏, 井嶋康二, 中野義郎. 斜め越流型水制周辺の流 れ構造の PIV 解析. 水工学論文集, Vol. 45, pp. 379-384, 2001.

8) 禰津家久, 鬼束幸樹, 矢野勝士. 河床形状がわんど流れ に及ぼす影響に関する研究. 水工学論文集, Vol. 46, pp. 559-564, 2002.

9) 重枝未玲, 秋山壽一郎, 浦勝, 有田由高. 非構造格子を用い た有限体積法に基づく平面 2 次元洪水流数值モデル. 水 工学論文集, Vol. 45, pp. 895-900, 2001.

10）前野詩朗, 宮内洋介, 森卓也. 植生が旭川の洪水流に及ぼ す影響の検討. 水工学論文集, Vol. 48, pp. 757-762, 2004.

11）重枝末玲, 朝位孝二, 坂本洋, 長太茂樹, 秋山壽一郎, 樋口 直樹, 重岡広美, 德永智宏. 樹木群を考慮した平面 2 次元 数值モデルによる乙津川の洪水流解析. 水工学論文集, Vol. 50, pp. 1171-1176, 2006.

12）(財) 国土技術センター. 第三回委員会資料, 財団法人国 土開発技術研究センター, 2001.

13）木村一郎, 北村忠紀, 熟見哲也, 武田誠, 鬼束幸樹, 庄建冶 朗, 大塚康司. 木曾川感潮域に設置された水制群周辺のワ ンド形成過程と河川環境に関する共同研究. 河川技術論 文集, Vol. 8, pp. 365-370, 2002.

14）辻本哲郎, 北村忠紀. 側岸部に植生群落を有する開水路流 れの横断混合機構に関する実験的研究. 土木学会論文集, Vol. 491/II-27, pp. 61-70, 1994.

15）木下良作. 航空写真による洪水流の解析解析 · 兴の乱流 構造と表面の流れかたの特性について. 日本写真測量学 会誌, Vol. 6, No. 1, pp. 1-17, 1967.

16) I. Nezu and H. Nakagawa. Cellular secondary currents in straight conduit. J. Hydraulic Eng., Vol. 110, No. 2, pp. 173-193, 1984.

(2007.9.30 受付) 